\title{
Taxonomic identity of the forms of Orestias agassii (Teleostei: Cyprinodontidae) from Chile: A morphological comparison with the syntypes of the species of Peru and Bolivia
}

\section{Identidad taxonómica de las formas de Orestias agassii (Teleostei: Cyprinodontidae) de Chile: una comparación morfológica con los sintipos de la especie de Perú y Bolivia}

\author{
Franco Cruz-Jofré ${ }^{1}$, Pamela Morales ${ }^{1}$, Yareli Esquer-Garrigos ${ }^{2}$, Irma Vila ${ }^{3}$, Bernard Hugueny ${ }^{2}$, \\ Philippe Gaubert ${ }^{2,4}$ \& Marco A. Méndez ${ }^{1,5^{*}}$ \\ ${ }^{1}$ Laboratorio de Genética y Evolución, Departamento de Ciencias Ecológicas, Facultad de Ciencias, Universidad de Chile, Las \\ Palmeras 3425, Casilla 653, Ñuñoa, Santiago, Chile. \\ 2UMR BOREA, Département Milieux et Peuplements Aquatiques, MNHN-CNRS 7208-IRD 207-UPMC, Muséum National \\ d'Histoire Naturelle, 43 rue Cuvier, 75231 Paris, France \\ ${ }^{3}$ Laboratorio de Limnología, Departamento de Ciencias Ecológicas, Facultad de Ciencias, Universidad de Chile. \\ ${ }^{4}$ Institut des Sciences de l'Evolution - IRD UMR 226, Université Montpellier 2, Place Eugène Bataillon - CC 64,34095 \\ Montpellier cedex 05, France. \\ Instituto de Ecología y Biodiversidad (IEB) Departamento de Ciencias Ecológicas, Facultad de Ciencias, Universidad de \\ Chile, Santiago, Chile. \\ *Author for correspondence.
}

\begin{abstract}
A morphological comparison of two populations assigned to Orestias agassii from the Chilean Altiplano with the syntypes from Peru and Bolivia was performed. The results suggest that populations of Chile do not match the form of Peru (Titicacalake), nevertheless the Isluga population could be related to $O$. agassii of Bolivia.
\end{abstract}

KeYwords: Orestias, altiplano, geometric morphometric.

RESUMEN

Se realizó una comparación morfológica de dos poblaciones asignadas a Orestias agassii del Altiplano chileno con los sintipos de Perú y Bolivia. Se sugiere que las poblaciones de Chile no corresponden a las de Perú (Lago Titicaca), sin embargo, la población de Isluga estaría relacionada con $O$. agassii de Bolivia.

Palabras clave: Orestias, altiplano, morfometría geométrica.

The fish diversity in the high Andes, is represented by only three native fish genera, the catfishes Astroblepus and Trichomycterus and the killifish Orestias (Vila et al 2007). The latter include 45 endemic species to the Altiplano (Eschmeyer \& Fong 2013), distributed in different aquatics systems, from Lake Lacsha in the center of Peru $\left(9^{\circ} \mathrm{S}\right)$ to the Ascotán salt pan in northern Chile $\left(22^{\circ} \mathrm{S}\right)$ (Lauzanne 1982; Vila 2006; Vila et al. 2011).

Orestias agassii Valenciennes 1846 is the species of the genus with the widest distribution in the Altiplano; it ranges from the Urubamba and Titicaca watersheds in Peru to the Uyuni salt pan in southern Bolivia and northern Chile (Arratia 1982, Parenti 1984, De la Barra et al. 2009). This species was first described by Valenciennes (1846), who characterized the morphology (Fig. 1a) and indicated the potential range of distribution in the Province of Corocoro, Bolivia $\left(17^{\circ} 10^{\prime} \mathrm{S} ; 68^{\circ} 27^{\prime} \mathrm{W}\right)$ and two lakes near Cuzco in Peru (Chincheros and Antonio). Also these authors generated a nomenclature conundrum because their use of three different binomials for $O$. agassii (O. agassizii, O. agassii and $O$. agassisii). Parenti (1984) made the first revision of the spellings used by Valenciennes (1846), establishing that O. agassii was the valid name (Cruz-Jofré et al. 2013). 
In 1895 Garman indicated that this species was abundant in Titicaca lake $\left(15^{\circ} 46^{\prime} \mathrm{S} ; 65^{\circ} 22^{\prime} \mathrm{W}\right)$. Thus the taxon Orestias agassii was originally ascribed to the Titicaca lake watershed; later studies added new localities in the Bolivian Altiplano (Parenti 1984).

The earliest references to $O$. agassii for Chile were made by Pellegrin (1904,1906), and then by Eigenmann (1927). These authors indicated that this species was present in the Ascotán salt pan $\left(21^{\circ} 29^{\prime} \mathrm{S}, 68^{\circ} 15^{\prime} \mathrm{W}\right)$, and that it was also found in the Loa river watershed and Calama. Later, Eigenmann \& Allen (1942) clarified the distribution in this area (Loa river), that corresponded to a typographical error (Figure 3 Page 5, see Eigenmann 1927). Mann (1954) affirmed that $O$. agassii is found across the Chilean Altiplano, in the Regions of Tarapacá, Antofagasta and Atacama, including a photograph of one individual of $O$. agassii, but did not indicate its provenance or define the localities in which this species would be found. Arratia (1982) suggested that the population of the Ascotán salt pan was a different species. Parenti (1984) described this species as O. ascotanensis, which has been validated using traditional morphological
(Martínez et al. 1999), chromosome evidence (Vila et al. 2010) and recently molecular phylogenetic analysis (Vila et al. 2013). Arratia (1982) also reviewed the populations of this genus in northern Chile (Parinacota Province $18^{\circ} 11^{\prime} \mathrm{S}$; $69^{\circ} 20^{\prime} \mathrm{W}$ ), described two new species (O. parinacotensis and $O$. laucaensis) and discard the presence of $O$. agassi at this latitude. Recently, Vila et al. (2013) in a molecular systematic study considered that three Chilean populations belong to $O$. agassii. The populations are those present in Isluga river $\left(19^{\circ} 15^{\prime} \mathrm{S}\right.$; $\left.68^{\circ} 42^{\prime} \mathrm{W}\right)$, Huasco salt pan $\left(20^{\circ} 15^{\prime} \mathrm{S}\right.$; $\left.68^{\circ} 52^{\prime} \mathrm{W}\right)$ and Collacagua river $\left(20^{\circ} 08^{\prime} \mathrm{S} ; 68^{\circ} 50^{\prime} \mathrm{W}\right)$. These authors suggest the existence of three independent lineages (species) that are currently classified as $O$. agassii, this implies that some of the populations present in Chile do not belong to this species.

The objective of this study is to clarify the presence of $O$. agassii in the Chilean Altiplano, based on the studies of Mann (1954), Arratia (1982) and the proposal of Vila et al. (2013), comparing the Chilean populations and the syntypes of the species from Peru (Parenti 1984) and Bolivia (EsquerGarrigos et al. 2013).
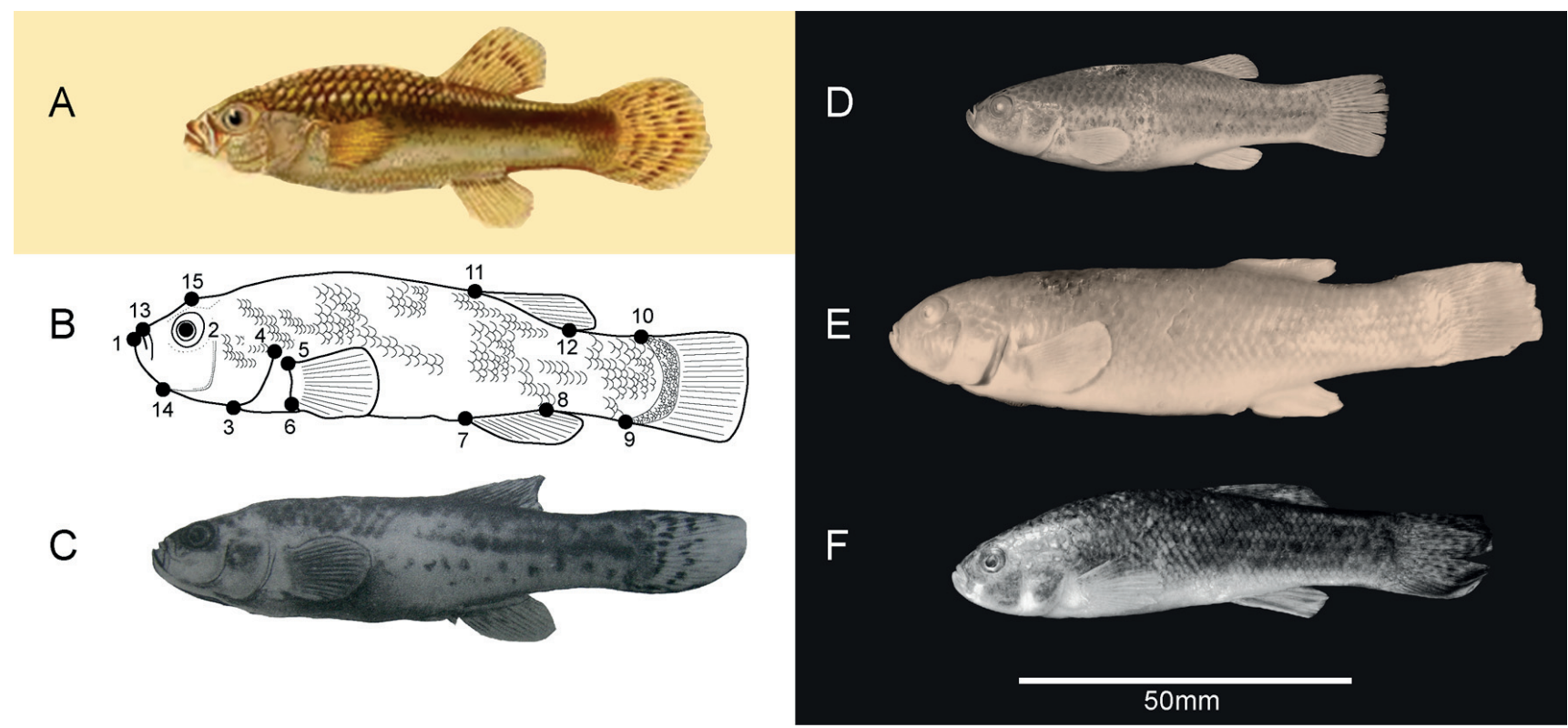

Figure 1. A: Drawing extracted from Valenciennes (1846) B: Landmarks (black points) utilized: (1) beginning of mandible; (2) center of eye; (3) base of isthmus; (4) beginning of gill cover or operculum; (5) and (6) insertion of pectoral fin; (7) and (8) beginning and end of anal fin; (9) and (10) insertion of caudal fin; (11) and (12) beginning and end of dorsal fin; (13) beginning of pre-maxilla; (14) sub-mandibular union; (15) dorsum of head. C: Photograph published by Mann (1954). D: Individual of Isluga river. E: Individual of Huasco salt pan. F: Individual of Puno bay (Titicaca Lake); photograph extracted from Parenti (1984).

Figura 1. A: Lámina extraída de Valenciennes (1846) B: Landmarks (puntos negros) utilizados: (1) inicio de mandíbula; (2) centro del ojo; (3) base del istmo; (4) inicio del opérculo; (5) y (6) inserción de la aleta pectoral; (7) y (8) inicio y término de la aleta anal, (9) y (10) inserción aleta caudal; (11) y (12) inicio y término de la aleta dorsal; (13) inicio pre maxila; (14) unión sub mandibular; (15) dorso de la cabeza. C: Fotografía publicada por Mann (1954). D: Individuo de río Isluga. E: Individuo del salar del Huasco. F: Fotografía extraída de Parenti (1984). 
We compared the body form of individuals from different localities by photographing a left lateral view with a digital camera (Nikon Coolpix 5400). We identified 15 landmarks or anatomically homologous points (Fig. 1B) using the TPS.DIG2 v2.16 program (Rohlf 2010). The coordinates of the specimens were aligned using the generalized Procrustes superimposition method. This was done for: A) the photograph published by Mann (1954) Fig. 1c; B) individuals from two Chilean localities, Isluga river (Fig. 1d) and Huasco salt pan (Fig. 1E), which are the same individuals analyzed by Vila et al. (2013); and C) the photographs of the individuals assigned as syntypes of the species from Umayo lake and Puno bay (Titicaca lake; Fig. 1f) in Peru and Poopo lake in Bolivia. In the analyses 47 females and two males were used (Table 1). Although, photographs of different sources could be not considered as replicate, in statistics sense, they are illustrative to solve the taxonomic identity of $O$. agassii Chilean forms. We performed a Canonical Variate Analysis (CVA) and a Principal Components Analysis (PCA) in the MORPHOJ program (Klingenberg 2011). Then we performed a discriminant function analysis (DFA corrected for sample size) in the SYSTAT program (SYSTAT, 2004) using the 26 principal components as variables and as classification groups the localities of Isluga, Huasco and Titicaca (PunoUmayo). The Poopo locality was excluded from the DFA. The results showed that the Chilean populations assigned to $O$. agassii are different independent units. This agrees with the phylogenetic results obtained by Vila et al. (2013). Also, the populations from the Titicaca watershed (Puno bay and Umayo lake) had taller bodies, larger heads and more oblique mouths than the individuals from Isluga and Huasco (Fig. 2). The individual photographed by Mann (1954) grouped with the individuals of the Isluga, which suggests

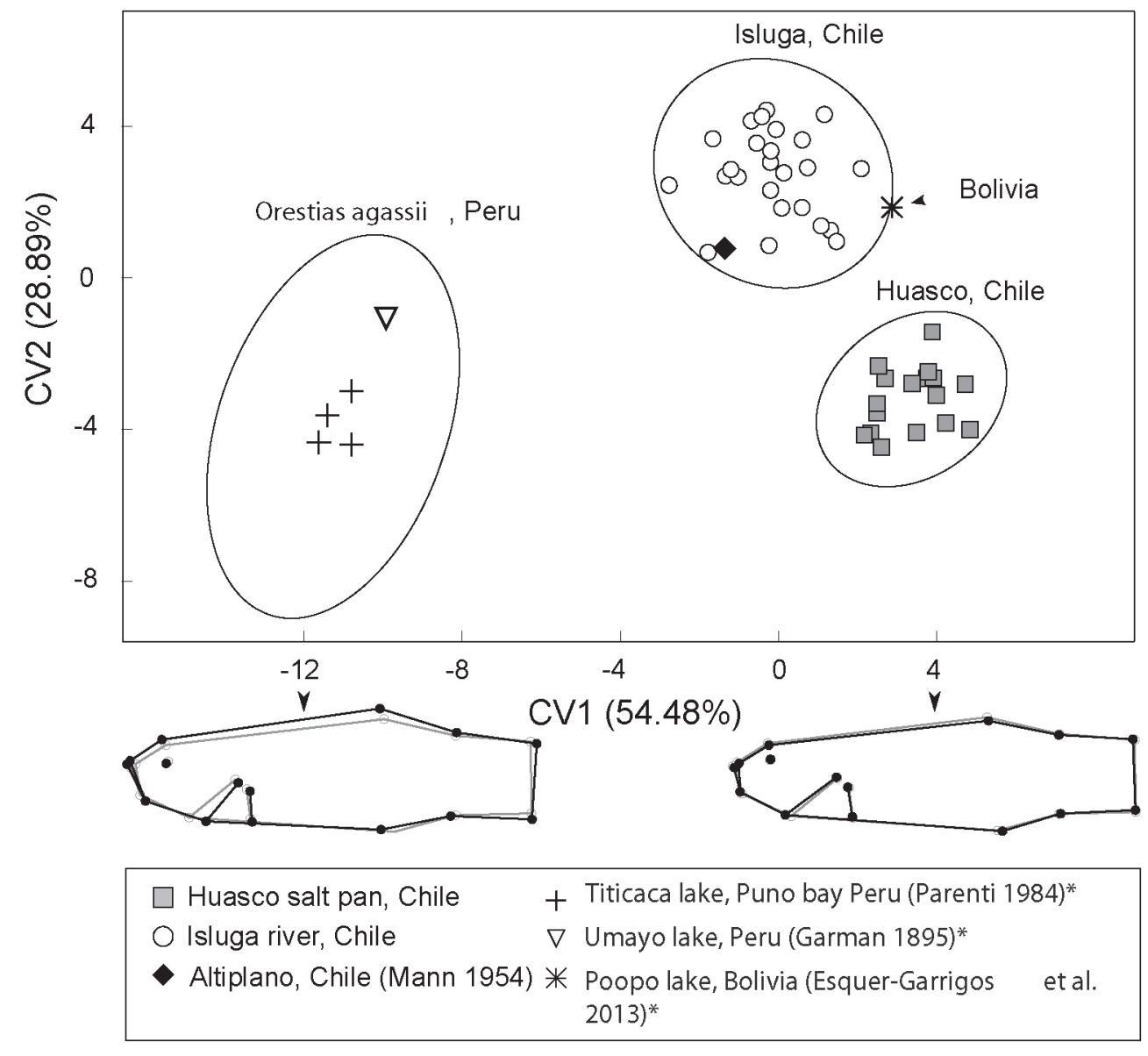

Figure 2 Canonical Variate Analysis (CVA) of the comparison among localities; 95\% probability ellipses are indicated. Under the CV1 axis are the diagrams of maximum change in the scale of values $(-12$ to +4$)$ in this canonical variable (in black the weighted form in the CV1 value; in grey the mean form of all individuals). *Syntypes of $O$. agassii.

FIGURA 2 Análisis de variables canónicas (CVA) de la comparación entre localidades. Se indican las elipses de equiprobabilidad de 0.95. Bajo el eje de CV1, se muestran los diagramas de cambio máximo escalado por los valores (-12 y 4) en esa variable canónica (en negro la forma ponderada en el valor de CV1; en gris, forma promedio de todos los individuos). *Sintipos de O. agassii. 
that it was collected in this locality. The results of the CVA showed that in the morphological space the individual from Poopo lake grouped with the Isluga population.

The DFA between localities showed 92\% correct classification. All localities showed high correct classification values of their individuals, $88 \%$ in Isluga, $94 \%$ in Huasco and $100 \%$ for the Titicaca watershed (Puno and Umayo) (Wilks' lambda $=0.005$ Approx. $F=10.008, \mathrm{df}$ $=52,40, \mathrm{p}<0.01)$.

Finally, the results of this study suggest that the forms of $O$. agassii in Chile do not match the form of the syntypes of $O$. agassii of Peru (Titicaca lake), however the Isluga population could be related as close to the Bolivian populations. This is also consistent with the proposal of Vila et al. (2013), who indicated that the forms assigned to this species in Chile conform a polyphyletic group, where Isluga population is the sister group of others populations of Orestias present in the Chilean Altiplano. The taxonomic status of these entities is being evaluated by our group using morphological (linear and meristic morphometry), karyotypes (chromosome number and chromosome banding) and genetic (mitochondrial and nuclear markers) characters.

TABLE 1. Material utilized in the morphological analyses.

TABLE 1. Material utilizado en los análisis morfológicos.

\begin{tabular}{llll}
\hline Code* & Locality & $\mathrm{N}^{*}(\mathrm{Sex})$ & References \\
\hline LGEUCH-ISL & Isluga river, Chile & 25 (females) & Present study \\
LGEUCH-HUA & Huasco salt pan, Chile & 17 (females) & Present study \\
Without code & Indeterminate, Chile & 1 (Indet.) & Mann 1954 \\
AMNH 52148 & Puno bay (Titicaca lake), Peru & 4 (2 males; 2 females) & Syntype, Parenti 1984 \\
& & & O. affinis Garman 1895. \\
MCZ 27698 & Umayo lake, Peru & 1 (Indet.) & $\begin{array}{l}\text { Syntype of } \text { agassizii } \\
\text { determined by Parenti } 1984\end{array}$ \\
& & & Syntype, Esquer et al. 2013 \\
\hline
\end{tabular}

* LGEUCH (Laboratorio de Genética y Evolución, Universidad de Chile); AMNH (American Museum of Natural History, New York); MCZ (Museum of Comparative Zoology, Cambridge); MNHN (Museum National d'Histoire Naturelle, Paris); N: number of individuals

\section{ACKNOWLEDGEMENTS}

We thank Hugo Salinas, Pablo Fibla, Moisés Valladares and Michel Sallaberry. This study was financed by FONDECYT 1110243, CONICYT 21120972, Programa de Cooperación Internacional CONICYT grants ECOS-CONICYT C10B02 and REDES130016. This study was authorized SUBPESCA, R.E. \#1042 and \#2231.

\section{BIBLIOGRAPHY}

Arratia, G. 1982. Peces del altiplano de Chile. In: Veloso, A. \& Bustos-Obregon E. (eds.). El Ambiente Natural y las Poblaciónes Humanas de los Andes del Norte Grande de Chile (Arica, Lat. 18²8'S) UNESCO, MAB-6, vol. 1, La Vegetación y los Vertebrados Inferiores de los Pisos Altitudinales entre Arica y Lago Chungará: 93-133; Montevideo, Uruguay (Oficina Regional de Ciencia y
Tecnología de la Unesco para América Latina y el Caribe). Cruz-Jofré, F., Valladares M.A., Vila I. \& Méndez M.A. 2013. The genus Orestias (Teleostei: Cyprinodontidae): nomenclatural errors in the assignation of species names. Zootaxa 3746 (4): 597-599.

De La Barra, E., Maldonado M., Carvajal-Vallejos F. \& Coronel J. 2009. Los peces del género Orestias (Cyprinodontiformes, Cyprinodontidae) en la Puna Meridional de Bolivia. Revista Boliviana de Ecología y Conservación Ambiental 26, 23-34.

Eigenmann, C.H. 1927. The fresh-water fishes of Chile. Memoirs of the National Academy of Sciences 22:1-63.

Eigenmann, C.H. \& Allen W.R. 1942. Fishes of western South America. I. The intercordilleran and Amazonian lowlands of Peru. II. The High Pampas of Peru, Bolivia and Northern Chile with a revision of the Peruvian Gymnotidae, and of the genus Orestias. University of Kentucky, Kentucky, USA.

EschmeYer, W. \& Fong J. 2013. Species of fishes by family/ subfamily. Online catalogue of fishes. Avalaible 
from: http://researcharchive.calacademy.org/research/ ichthyology/catalog/fishcatmain.asp. Electronic version (accessed 16 April 2013).

Esquer-Garrigos, Y., Hugueny B., Koerner K., Ibañez C., Bonillo C., Pruvost P., Causse R., Cruaud C. \& Gaubert P. 2013. Non-invasive ancient DNA protocol for fluidpreserved specimens and phylogenetic systematics of the genus Orestias (Teleostei: Cyprinodontidae). Zootaxa, 3640 (3), 373-394

Garman, S.W. 1895. The cyprinodonts. Memoirs of the Museum of Comparative Zoology at Harvard College, Cambridge, USA. $150-152$

KlingenberG, C.P. 2011. MORPHOJ: an integrated software package for geometric morphometrics. Molecular Ecology Resources 11: 353-357.

Lauzanne, L. 1982. Les Orestias (Pisces, Cyprinodontidae) du Petit lac Titicaca. Revue d'Hydrobiologie Tropicale, 15, 39-70.

Mann, G. 1954. Vida de los peces en aguas chilenas. Ministerio de Agricultura, Investigaciones Veterinarias. Facultad de Filosofía y Educación, Universidad de Chile, Santiago, Chile. 195-196.

Martínez, G., Bugueño N. \& Vila I.1999. Orestias ascotanensis Parenti 1984 en el Salar de Ascotán. Noticiario Mensual del Museo Nacional de Historia Natural, Chile, 339: 7-12.

Parenti, L. 1984. A taxonomic revision of the Andean killifish genus Orestias (Cyprinodontiformes, Cyprinodontidae). Bulletin of the American Museum of Natural History 178: 107-214.

Pellegrin, J. 1904. Sur les Pharyngiens Inférieurs chez les Poissons du genre Orestias. Comptes Rendus de l'Académie des Sciences, Paris, 139: 682-684

Pellegrin, J. 1906. Poissons, In: Meveu-Lemaire, M., Les lac des plateau de 1'Amerique du Sud, Paris, France, pp. 112-137.

RoHLF, F.J. 2010. TpsDig v2.16. Department of Ecology and Evolution. State University of New York at Stony Brook.

Systat Software, Inc. 2004. SYSTAT 11 Statistic. United States of America.

Valenciennes, A.1846. Chapitre XII Des Orestias En: Cuvier G. \& Valenciennes A. (eds) Histoire Naturelle des Poissons (Volume XVIII, Livre XVIII): 221-244. Paris, Francia.

VILA, I. 2006. A new species of Killifish in the Genus Orestias (Teleostei; Cyprinodontidae) from the Southern High Andes, Chile. Copeia, 2006 (3), 471-477.

Vila, I. Pardo R. \& S. Scott. 2007. Freshwater fishes of the Altiplano. Aquatic Ecosystem Health and Management, 10: 201-211.

Vila, I., Scott S., Lam N., Iturra P. \& Méndez M.A. 2010. Karyological and morphological analysis of divergence among species of the killifish genus Orestias (Teleostei: Cyprinodontidae) from the southern Altiplano. In: Nelson J.S., Schultze H.P. \& Wilson M.V.H. (eds) Origin and phylogenetic interrelationships of Teleosts: 471-479. Verlag Dr. Friedrich Pfeil, München, Germany

Vila, I., Scott S., Méndez M.A., Valenzuela F., Iturra P \& Poulin E. 2011. Orestias gloriae, a new species of cyprinodontid fish from saltpan spring of the southern high Andes (Teleostei: Cyprinodontidae). Ichthyological Exploration of Freshwaters, 22, 345-353.

Vila, I., Morales P., Scott S., Poulin E., Véliz D., Harrod C. \& MÉndez M.A. 2013. Phylogenetic and phylogeographic analysis of the genus Orestias (Teleostei; Cyprinodontidae) in the Southern Chilean Altiplano: the relevance of ancient and recent divergence processes in speciation. Journal of Fish Biology 82: 927-943.

Recibido: 26.11 .13

Aceptado: 13.03.14 